\title{
Analiza stopnia implementacji postanowień konwencji dotyczących bezpaństwowców z 1954 r. i 1961 r. w prawie polskim 1
}

Analysis of the degree of implementation of provisions of the conventions on stateless persons of 1954 and 1961 in the Polish legal system (WAPM-991/18): The subject of the opinion is an analysis of the degree of implementation of provisions of the Convention relating to the Status of Stateless Persons of 1954 and the Convention on the Reduction of Statelessness of 1961 in the Polish legal system, in particular: determination of the rules of the Conventions which are present in Polish law; an analysis of possible inconsistencies between the Conventions and Polish law; an indication of legislator's obligations that would arise, if Poland became bound by these Conventions.

\author{
Keywords: foreigner, stateless person, citizenship, ratification, international agre- \\ ement \\ Słowa kluczowe: cudzoziemiec, bezpaństwowiec, obywatelstwo, ratyfikacja, umowa \\ międzynarodowa
}

\section{Przedmiot opinii}

Przedmiotem opinii jest analiza stopnia implementacji postanowień Konwencji o statusie bezpaństwowców z 1954 r. (dalej: konwencja z 1954 r.) i Konwencji o ograniczeniu bezpaństwowości z 1961 r. (dalej: konwencja z 1961 r.) w prawie polskim, a w szczególności:

- ustalenia, jakie normy wymienionych konwencji są obecne prawie polskim,

- czy istnieje sprzeczność między postanowieniami wymienionych konwencji a prawem polskim,

1 Opinia $w$ sprawie analizy stopnia implementacji postanowień konwencji dotyczacych bezpaństwowców z 1954 r. i 1961 r.w prawie polskim sporządzona 13 czerwca 2018 r. na zamówienie posła Klubu Poselskiego Nowoczesna; BAS-WAPM 991/18. 
- jakie obowiązki ustawodawcy zaktualizowałyby się w razie związania się tymi konwencjami.

Pełna odpowiedź na te pytania wymagałaby gruntownej analizy nie tylko prawodawstwa, ale także polskiej praktyki sądowej i administracyjnej. Zagadnienia w zakresie referowania prawa polskiego zostaną przedstawione w podstawowym, głównie ustawowym kształcie. Odpowiedzi na postawione pytania zostaną przy tym przedstawione na tle ogólnej problematyki bezpaństwowości, charakterystyki ogólnej regulacji konwencyjnych, relacji do przyjętych już zobowiązań międzynarodowych Polski dotyczących bezpaństwowców, wreszcie określenia relacji zakresów obu konwencji do prawa polskiego. Trzeba sobie przy tym zdawać sprawę, że gdy mowa o prawie polskim, mamy na uwadze tylko prawo stworzone przez polskiego prawodawcę. Tymczasem częścią prawa polskiego w rozumieniu art. 91 ust. 1 Konstytucji jest także wiążące RP prawo międzynarodowe w szczególności traktatowe, ale również zwyczajowe czy zawarte w innych źródłach prawa międzynarodowego (art. 9 Konstytucji).

Do potrzeb niniejszej opinii na określenie konwencji z 1954 r. i konwencji z 1961 r. używany będzie także zwrot „konwencje o bezpaństwowcach”.

\section{Zjawisko bezpaństwowości - uwagi ogólne}

Zjawisko bezpaństwowości jest znane od dłuższego czasu. Uzyskało ono znaczenie wraz z powszechnym wprowadzeniem przez państwa obywatelstwa w XIX wieku. Przyczyny bezpaństwowości są różne. Do czasu ukształtowania międzynarodowej ochrony praw człowieka uznawano, że przyznawanie obywatelstwa stanowi prerogatywę państw, a nie prawo jednostki. W związku z tym państwa mogły w określonych sytuacjach pozbawiać obywatelstwa (np. wskutek opuszczenia własnego państwa), nie interesując się tym, czy osoba pozbawiona uzyskała inne obywatelstwo. Obywatelstwo można było stracić także przez zawarcie małżeństwa $\mathrm{z}$ cudzoziemcem lub rozwód. Jeśli taki skutek wiązano z małżeństwem lub rozwodem (u źródeł problemu leżało nierównoprawne traktowanie kobiet), a wskutek tych wydarzeń zainteresowany nie nabywał lub nie odzyskiwał obywatelstwa sprzed wydarzenia, stawał się bezpaństwowcem. Obywatelstwa można było także nie nabyć (np. dziecko urodzone z rodziców niemających obywatelstwa w państwie, gdzie obowiązywała zasada prawa krwi). Z prawnego punktu widzenia bezpaństwowość była postrzegana jako konsekwencja tzw. negatywnego zbiegu ustaw o obywatelstwie.

W pierwszej połowie XX wieku wspólnota międzynarodowa podjęła wysiłki, aby wyeliminować przypadki bezpaństwowości. Zdołano w szczególności wynegocjować Konwencję w sprawie pewnych zagadnień dotyczących kolizji ustaw o obywatelstwie oraz protokół dotyczący przypadku bezpaństwowości, 
podpisane w Hadze 12 kwietnia $1930 \mathrm{r}^{2}$. Polska związała się tymi traktatami w 1937 r. (Dz.U. nr 47, poz. 361, ze zm.) 3. Przyjęto w niej zasadę, że decydentem w kwestiach obywatelstwa jest państwo, aczkolwiek działające zgodnie z prawem międzynarodowym dotyczącym obywatelstwa (art. 1 konwencji). Konwencja regulowała zagadnienie negatywnego i pozytywnego zbiegu ustaw o obywatelstwie (podwójne/wielorakie obywatelstwo). Unormowała zagadnienie skutków prawnych opuszczenia własnego państwa, zamążpójścia, urodzenia się dzieci lub naturalizacji rodziców, przysposobienia. Szczególne znaczenie dla zwalczania bezpaństwowości miał protokół dołączony do konwencji, w którym uregulowano przede wszystkim przypadek urodzenia się dziecka na terytorium państwa z matki mającej obywatelstwo tego państwa i ojca niemającego obywatelstwa lub o obywatelstwie nieznanym (art. 1).

Po II wojnie światowej nadal obowiązuje zasada, że państwo decyduje o tym, kto i na jakich warunkach zostaje jego obywatelem albo obywatelstwo to traci ${ }^{4}$. Wojna ukazała nowe oblicza bezpaństwowości i uchodźstwa, czasem związanego także z bezpaństwowością. Ponadto w II połowie XX wieku i początkach XXI wieku obserwujemy fale migracyjne o różnym podłożu, których elementem jest również zjawisko bezpaństwowości.

Według Wysokiego Komisarza ONZ ds. Uchodźców obecnie ok. 10 milionom ludzi odmawia się obywatelstwa. Wskazuje się przy tym cztery zasadnicze przyczyny bezpaństwowości: 1) luki w ustawodawstwie dotyczącym obywatelstwa; 2) negatywny zbieg ustaw o obywatelstwie lub stosowanie ustawodawstwa dyskryminacyjnego; 3) pojawienie się nowych państw i zmiany granic; 4) utrata lub pozbawienie obywatelstwa, np. z uwagi na długoterminowe przebywanie poza granicami państwa lub wskutek zmian w prawie, które wprowadzają kryteria dyskryminacyjne $e^{5}$.

\section{Charakterystyka ogólna konwencji o bezpaństwowcach}

Po II wojnie światowej zawarto dwie umowy międzynarodowe specyficznie poświęcone problematyce bezpaństwowców. Są to Konwencja o statusie bezpań-

2 Konwencja weszła w życie 1 lipca 1937 r. Związało się nią tylko 13 państw, a po II wojnie światowej dodatkowo 11 państw, „League of Nations Treaty Series” vol. 179, s. 89.

3 Ratyfikacja nastąpiła za zgodą wyrażoną w ustawie z 5 marca 1934 r., Dz.U. nr 27, poz. 217. Konwencja i protokół wciąż wiążą RP, aczkolwiek ze zmianami wynikającymi z późniejszych zobowiązań międzynarodowych Polski.

4 B. Nascimbene, Le droit de la nationalité et le droit des organisations d'intégration régionales. Vers de nouveaux statuts de résidents?, RCADI 2013, vol. 367, s. 286-288.

5 Zob. http://www.unhcr.org/stateless-people.html. 
stwowców z 28 września 1954 r. ${ }^{6}$ oraz Konwencja o ograniczeniu bezpaństwowości z 30 sierpnia 1961 r. ${ }^{7}$. Oba traktaty, jako wynegocjowane w ramach ONZ ${ }^{8}$, aspirują do powszechności, chociaż zakres ich akceptacji pozostawia wiele do życzenia (są one wiążące dla mniej niż połowy państw świata) ${ }^{9}$.

Konwencja o statusie bezpaństwowców z 1954 r. składa się z preambuły i 42 artykułów. Zawiera definicję bezpaństwowca, reguluje zobowiązania ogólne i podstawowe zasady traktowania i ochrony bezpaństwowców (art. 1-11) oraz określa ich status prawny, położenie w zakresie zatrudnienia i zarobkowania, opieki społecznej, nadawania obywatelstwa, wydalenia, swobody przemieszczania się, traktowania w sprawach administracyjnych i finansowych (art. 12-32). Konwencja zawiera postanowienia końcowe, w tym klauzule rozwiązywania sporów, wiązania się, terytorialną i federalną, wejścia w życie, przeglądową (art. 33-42). Zgodnie z konwencją jej stroną mogą zostać tylko państwa. Mogą one formułować zastrzeżenia, jakkolwiek z wyłączeniem art. 1 (definicja bezpaństwowca), art. 3 (zakaz dyskryminacji), art. 4 (standard traktowania narodowego w odniesieniu do wolności praktyk religijnych i edukacji religijnej dzieci), art. 16 ust. 1 (prawo swobodnego dostępu do sądu na terytorium państw-stron) oraz art. 33-42 (postanowienia końcowe $)^{10}$. Zastrzeżenia mogą być wycofane w każdej chwili (przez zawiadomienie Sekretarza Generalnego ONZ). Każde państwo, które związało się konwencją, ma obowiązek informacyjny, polegający na przedstawieniu Sekretarzowi Generalnemu ONZ (jako depozytariuszowi umowy - art. 42) praw i regulacji wykonujących konwencję (art. 33). Każde państwo-strona może wypowiedzieć konwencję, przy czym skuteczność tego oświadczenia następuje po

6 UNTS vol. 360, s. 117. Konwencja weszła w życie 6 czerwca 1960 r. Jej stronami jest 90 państw. Spośród państw członkowskich Unii Europejskiej, poza Polską, jej stroną nie są Cypr, Estonia, Malta.

7 UNTS vol. 989, s. 175. Konwencja weszła w życie 13 grudnia 1975 r. Jej stronami jest 71 państw. Spośród państw członkowskich Unii Europejskiej, poza Polską, jej stroną nie są Cypr, Estonia, Francja, Grecja, Hiszpania, Malta, Słowenia.

8 Nad projektami konwencji dotyczących bezpaństwowców pracowała Komisja Prawa Międzynarodowego ONZ. Komisja zaproponowała w 1954 r. projekty konwencji o eliminacji przyszłej bezpaństwowości i o redukcji przyszłej bezpaństwowości, które nie spotkały się z uznaniem państw. W 1961 r. natomiast opracowała Konwencję o ograniczeniu bezpaństwowości, http://legal.un.org/ilc/texts/6_1.shtml.

9 Wysoki Komisarz ONZ ds. Uchodźców opublikował Podręcznik o ochronie bezpaństwowcówwedługKonwencjiz 1954r. dotyczącejstatusubezpaństwowców, Genewa 2014, http://www.unhcr.org/dach/wp-content/uploads/sites/27/2017/04/CH-UNHCR _Handbook-on-Protection-of-Stateless-Persons.pdf. Dostępna też jest wersja w języku polskim, lecz zawiera liczne błędy, http://www.refworld.org/cgi-bin/texis/vtx/rwmain/opendocpdf.pdf? reldoc $=y \&$ docid=54c0b8844.

10 Zastrzeżenia o zróżnicowanym zakresie złożyły do konwencji m.in. Austria, Bułgaria, Czechy, Dania, Finlandia, Francja, Hiszpania, Łotwa, Niderlandy, Niemcy, Portugalia, Rumunia, Słowacja, Szwecja, Węgry, Włochy, Zjednoczone Królestwo. 
upływie roku od daty otrzymania notyfikacji przez Sekretarza Generalnego ONZ (art. 40 ust. 2).

Konwencja o ograniczeniu bezpaństwowości z 1961 r. obejmuje bardzo krótką preambułę oraz 21 artykułów. Reguluje się w niej poszczególne przypadki mające zapobiec bezpaństwowości (art. 1-10), a ponadto zawiera postanowienia dotyczące reguł odnoszących się do działania zobowiązań konwencyjnych (art. 11-13) oraz klauzule rozwiązywania sporów, terytoriów niesamodzielnych, związania się i wejścia w życie, zastrzeżeń, wypowiedzenia, depozytariusza (jest nim Sekretarz Generalny ONZ) i rejestracji (art. 14-21).

Konwencją z 1961 r. również mogą związać się tylko państwa. Mogą one składać zastrzeżenia, z wyjątkiem wszakże art. 11 (obowiązek promowania ustanowienia w ONZ organu odpowiedzialnego za rozpatrywanie roszczeń jednostek uprawnionych na mocy konwencji i udzielenie pomocy w przedłożeniu roszczenia właściwemu organowi), art. 14 (klauzula rozwiązywania sporów) i art. 15 (klauzula terytoriów niesamodzielnych). Oznacza to w praktyce, że niedopuszczalne jest złożenie zastrzeżenia do jakiegokolwiek z postanowień materialnych konwencji (art. 1-10) ${ }^{11}$. Chociaż konwencja milczy w tej sprawie, to zastrzeżenia mogą być wycofane zgodnie z zasadami ogólnymi prawa traktatów (art. 22 konwencji wiedeńskiej o prawie traktatów ${ }^{12}$ ). Istnieje możliwość wypowiedzenia konwencji, przy czym staje się ono skuteczne $\mathrm{z}$ upływem roku od daty otrzymania przez Sekretarza Generalnego ONZ notyfikacji dotyczącej tego wypowiedzenia (art. 19 ust. 1).

Przedstawione konwencje nie dysponują skutkiem bezpośrednim (nie zawierają norm samowykonalnych). Każda z nich, a zwłaszcza jednoznacznie konwencja z 1954 r. (art. 33), wymaga podjęcia działań implementacyjnych. Oznacza to, że w swoim działaniu jest uzależniona od wydania aktów prawa krajowego.

Umowy międzynarodowe mogą odzwierciedlać reguły prawa zwyczajowego albo też je, w przypadku odpowiedniej reprezentatywności i praktyki państw niebędących stronami umowy, generować. Sytuacja ta nie zachodzi co do zasady w przypadku konwencji o bezpaństwowcach. $\mathrm{Z}$ całą pewnością nie są to konwencje o charakterze kodyfikacyjnym. Spory dotyczące uzgadniania ich treści, ograniczony krąg państw-stron oraz niepewna praktyka państw niebędących ich stronami podważają też, poza wyjątkowymi sytuacjami ${ }^{13}$, dopuszczalność kwalifikowania ich jako generujących reguły zwyczajowe.

11 Państwa obchodziły jednak ten zakaz przez formułowanie deklaracji interpretacyjnych. Zastrzeżenia lub deklaracje o zróżnicowanym zakresie złożyły do konwencji m.in. Austria, Belgia, Francja, Irlandia, Litwa, Niemcy i Zjednoczone Królestwo.

12 Konwencja wiedeńska o prawie traktatów sporządzona w Wiedniu dnia 23 maja 1969 r., Dz.U. 1990, nr 74, poz. 439, załącznik.

13 Zob. np. W.Th. Worster, The Presumption of Customary International Law: A Case Study of Child Stateleness, https://papers.ssrn.com/sol3/papers.cfm?abstract_id=3091912. 


\section{Konwencje o bezpaństwowcach a zakres zobowiązań międzynarodowych RP}

Położenie prawne bezpaństwowców jest regulowane w prawie międzynarodowym na dwóch poziomach. Poziom pierwszy, minimalny, wyznacza międzynarodowa ochrona praw człowieka. Innymi słowy, skoro ochrona ta co do zasady jest przeznaczona do ochrony wszystkich osób podlegających jurysdykcji państw ze względu na godność osobową, którą mają, to przysługuje ona również bezpaństwowcom. Wyjątki od tej zasady, dotyczące ochrony obywateli bądź związane jednoznacznie ze statusem obywatelskim (cudzoziemca), są stosunkowo nieliczne. Oznacza to, że w zakresie, w jakim Polska związała się umowami międzynarodowymi dotyczącymi ochrony praw człowieka, zobowiązała się ona także do zagwarantowania odpowiednich praw i wolności bezpaństwowcom. W traktatach dotyczących ochrony praw człowieka bezpaństwowość czy bezpaństwowcy na ogół nie stanowią specyficznego przedmiotu regulacji.

Z tych założeń ideowych wyrasta Uniwersalna deklaracja praw człowieka z 10 grudnia 1948 r., która stała się częścią tzw. międzynarodowej karty praw człowieka i podstawą opracowania paktów praw człowieka, a także wywarła wpływ na liczne dokumenty międzynarodowe, w tym traktaty powszechne i regionalne z dziedziny praw człowieka. Nie wspomina ona o bezpaństwowości, ale pośrednio dotyka tej kwestii, regulując prawo do obywatelstwa i zakaz arbitralnego pozbawiania obywatelstwa (art. 15) oraz gwarantując równość praw kobiet i mężczyzn w odniesieniu m.in. do zawierania i rozwiązania małżeństwa (art. 16 ust. 1). Generalnie postanowienia deklaracji (tak prawa osobiste i polityczne, jak i gospodarcze, socjalne i kulturalne) w pełnym zakresie stosuje się do bezpaństwowców.

Również międzynarodowe pakty praw człowieka z 16 grudnia 1966 r. $^{14}$, których Polska jest stroną ${ }^{15}$, nie różnicują zasadniczo położenia jednostki chronionej. Jedynie wyjątkowo relatywizują ją do obywatela lub cudzoziemca (np. art. 13 i 25 paktu praw obywatelskich i politycznych). Skutek prewencyjny w odniesieniu do bezpaństwowości ma np. art. 24 ust. 3 paktu praw obywatelskich i politycznych, który zobowiązuje do przyznania obywatelstwa każdemu urodzonemu pod jurysdykcją państwa dziecku ${ }^{16}$.

14 Pakt praw obywatelskich i politycznych wszedł w życie 23 marca 1976 r. Jego stronami jest 171 państw, UNTS vol. 999, s. 171; Pakt praw gospodarczych, socjalnych i kulturalnych wszedł w życie 3 stycznia 1976 r. Jego stronami jest 168 państw, UNTS vol. 993, s. 3 .

15 Pakty obowiązują od 18 czerwca 1977 r., Dz.U. nr 38, poz. 167 i 169.

16 Zob. szerzej o zastosowaniu postanowień paktu praw obywatelskich i politycznych do bezpaństwowców: International Covenant on Civil and Political Rights. Quick Reference Guide. Statelessness and Human Rights Treaties, UNHCR, October 2016, http:// www.refworld.org/pdfid/58c25e3a4.pdf. 
Z podejściem tym koresponduje art. 37 Konstytucji RP, który stanowi, że: 1. Kto znajduje się pod władza Rzeczypospolitej Polskiej, korzysta z wolności i praw zapewnionych $w$ Konstytucji.

2. Wyjątki od tej zasady, odnoszące się do cudzoziemców, określa ustawa.

Postanowienie ust. 2 jest o tyle nieścisłe, że sama Konstytucja odnosi niektóre prawa i wolności oraz obowiązki jedynie do obywateli (np. art. 35, art. 52 ust. 4, art. 55, art. 60-62, art. 67, art. 68 ust. 2, art. 82, art. 85).

Drugi poziom jest specyficznie związany z regulacją międzynarodową kwestii ograniczenia przypadków bezpaństwowości oraz położenia prawnego bezpaństwowców. Regulacja ta odbywa się w formie specyficznej (umowa dotycząca wyłącznie zagadnienia bezpaństwowości lub bezpaństwowców) albo na zasadzie pars pro toto, tj. w umowach ogólniejszej natury pojawiają się postanowienia wyraźnie dotyczące bezpaństwowości lub bezpaństwowców. Przykładami takiego ujęcia są konwencje o bezpaństwowcach, wspomniana wcześniej konwencja z 1930 r. o kolizji ustaw o obywatelstwie wraz z protokołem dotyczącym bezpaństwowości, jak również konwencja o obywatelstwie kobiet zamężnych z 20 lutego 1957 r. ${ }^{17}$, której Polska jest stroną (Dz.U. 1959, nr 56, poz. 334), czy konwencja Rady Europy o obywatelstwie z 6 listopada 1997 r. ${ }^{18}$, której Polska nie ratyfikowała.

\section{Konwencje o bezpaństwowcach a prawo polskie}

Zagadnienie relacji między konwencjami a prawem polskim zostanie przedstawione z perspektywy konkretnych pojęć i instytucji regulowanych konwencjami. Korespondujące $\mathrm{z}$ nimi prawo polskie będzie przywoływane w każdym przypadku z osobna. W wyniku porównania regulacji udzielona zostanie odpowiedź na pytanie o zgodność prawa polskiego z konwencjami, i w związku z tym ustalona ewentualna niezgodność.

Ponadto, mając na uwadze zakres regulacji konwencji o bezpaństwowcach, zasadne jest uprzednie zwrócenie uwagi na konwencję o ograniczeniu bezpaństwowości z 1961 r., a następnie konwencję o statusie bezpaństwowców z 1954 r. Podczas gdy pierwsza z nich dotyczy samego zapobiegania bezpaństwowości czy też reagowania na przypadki bezpaństwowości, druga $\mathrm{z}$ nich określa $\mathrm{w}$ szczególności standardy ochrony, jakie powinny być zapewnione bezpaństwowcom. Jedynym odstępstwem od tej zasady będzie kwestia posługiwania się terminem „bezpaństwowiec” w prawie polskim w związku z jego definicją zawartą w konwencji z 1954 r.

17 Konwencja weszła w życie 11 sierpnia 1958 r., UNTS vol. 309, s. 65. Jej stronami są 74 państwa.

18 European Treaty Series No. 166. 


\section{Pojęcie bezpaństwowca}

W obu rozważanych konwencjach kluczowym pojęciem jest pojęcie bezpaństwowca. Normuje je przede wszystkim konwencja z 1954 r., w której rozumieniu bezpaństwowcem jest osoba nieuznawana za obywatela żadnego państwa (także niebędącego stroną konwencji) w zakresie obowiązywania jego prawa (art. 1 ust. 1). Konwencja z $1961 \mathrm{r}$. nie podaje autonomicznej definicji bezpaństwowca. $\mathrm{Z}$ jej postanowień można jednak wywieść wniosek, że rozumienie to jest, co do zasady, zbieżne z definicją zawartą $\mathrm{w}$ art. 1 konwencji z $1954 \mathrm{r}$.

W praktyce międzynarodowej uważa się, że definicja bezpaństwowców z konwencji z 1954 r. dotyczy jedynie tzw. bezpaństwowców de iure. Tymczasem mamy również do czynienia z tzw. bezpaństwowcami de facto, tj. osobami, które opuściły państwo swojej przynależności i nie korzystają już z ochrony i pomocy władz krajowych, gdyż te odmawiają jej tego bądź osoba taka zrzekła się pomocy i ochrony ze strony swojego kraju albo jest niezdolna lub nie chce z ważnych przyczyn skorzystać z niej ${ }^{19}$. Definicja ta dotyczy zatem osób, które formalnie mają obywatelstwo państwa trzeciego, lecz nie korzystają z praw i nie wykonują obowiązków z nim związanych.

W prawie polskim, poza incydentalnymi przypadkami, nie używa się terminu bezpaństwowiec. Jest tak, mimo że np. dyrektywy Unii Europejskiej, które transponowano do prawa polskiego, posługują się tym terminem nawet w samych nazwach aktów. Konstytucja używa jedynie określenia „cudzoziemiec”. Z kolei w ustawie o cudzoziemcach ${ }^{20}$ stwierdza się, że cudzoziemcem jest każda osoba, która nie posiada obywatelstwa polskiego (art. 3 pkt 2). Jest nim zatem także osoba niemająca żadnego obywatelstwa, czyli bezpaństwowiec ${ }^{21}$, jak również bezpaństwowiec faktyczny. Oznacza to, że regulacje prawa polskiego dotyczące cudzoziemców (także konstytucyjne) należy stosować mutatis mutandis do bezpaństwowców. Jeśli zatem z przepisów prawa polskiego nie będzie wynikało, że z prawami, wolnościami lub obowiązkami cudzoziemca związany jest nierozerwalnie status obywatela innego państwa niż Polska, te prawa, wolności i obowiązki należy odnosić także do bezpaństwowców.

19 Zob. UNHCR, Guidelines on Statelessness No. 1: The definition of „Stateless Person" in Article 1(1) of the 1954 Convention relating to the Status of Stateless Persons, HCR/GS/12/01, 20 February 2012, http://www.refworld.org/pdfid/4f4371b82.pdf. Definicja bezpaństwowca de facto nie ma jednak charakteru legalnego. Zob. też np. M. Stiller, Statlessness in International Law: A Historic Overview, DAJV Newsletter 2012, No. 3.

20 Ustawa z 12 grudnia 2013 r. o cudzoziemcach, t.j. Dz.U. 2017, poz. 2206, ze zm. Stanowi ona w wysokim stopniu wykonanie dyrektyw Unii Europejskiej.

${ }^{21}$ Tak też na tle poprzednio obowiązującej ustawy o cudzoziemcach z 2003 r., która zawierała identyczne sformułowanie, Sąd Apelacyjny w Warszawie, w postanowieniu z 20 czerwca 2013 r., sygn. akt II AKz 429/13. 
Mniej konsekwentna od ustawy o cudzoziemcach jest ustawa o udzielaniu cudzoziemcom ochrony na terytorium Rzeczypospolitej Polskiej ${ }^{22}$. Wprawdzie zgodnie z jej art. 2 pkt 4 cudzoziemcem $w$ rozumieniu tej ustawy jest cudzoziemiec $\mathrm{w}$ rozumieniu ustawy o cudzoziemcach, a zatem zgodnie $\mathrm{z}$ przyjętą interpretacją także bezpaństwowiec, to jednak $\mathrm{w}$ dwóch dalszych przepisach wspomina się wprost o bezpaństwowcach. W ten sposób art. 21 ust. 1 pkt 6 stanowi, że cudzoziemca pozbawia się statusu uchodźcy, jeżeli po nadaniu tego statusu właściwy organ stwierdził, że cudzoziemiec, będąc bezpaństwowcem, może powrócić do państwa, w którym miał poprzednio stałe miejsce zamieszkania, z powodu ustania okoliczności, w związku z którymi uzyskał status uchodźcy, i nie przedstawił przekonywających powodów związanych z prześladowaniami, w związku z którymi uzyskał ten status, lub innych powodów uzasadnionej obawy przed prześladowaniem, uzasadniających jego odmowę powrotu do tego państwa. Z kolei w art. 22 ust. 2a stwierdza się, że cudzoziemca nie pozbawia się ochrony uzupełniającej z przyczyny, o której mowa w ust. 1 pkt 1, jeżeli może powołać się na przekonywające powody związane z poprzednio doznaną poważną krzywdą, uzasadniające jego odmowę skorzystania z ochrony państwa, którego obywatelstwo posiada, albo - w przypadku bezpaństwowca - z ochrony państwa, w którym miał poprzednio stałe miejsce zamieszkania.

Brak jednoznacznego rozróżnienia cudzoziemca i bezpaństwowca może powodować praktyczne problemy związane z odpowiednim wypełnianiem wymogów konwencyjnych.

\section{Zapobieganie bezpaństwowości}

\section{- Obowiązek nadania obywatelstwa ${ }^{23}$}

\section{- Standard konwencyjny}

Obowiązek nadania obywatelstwa został sformułowany przede wszystkim w konwencji z 1961 r. Konwencja z 1954 r. unormowała to zagadnienie ogólnie, tylko w jednym postanowieniu. Zgodnie z jej art. 32: Państwa Strony niniejszej Konwencji, $w$ takim zakresie jak to możliwe, ułatwiq asymilacje i nadanie obywatelstwa bezpaństwowca. W szczególności podejma działania mające na celu usprawnienie procedur nadawania obywatelstwa i zmniejszenie, $w$ takim stopniu jaki jest możliwy, opłat $i$ kosztów takich procedur.

Tymczasem konwencja z $1961 \mathrm{r}$. reguluje to zagadnienie w kilku postanowieniach. W art. 1 wprowadza obowiązek nadania obywatelstwa osobie urodzo-

22 Ustawa z 13 czerwca 2003 r o udzielaniu cudzoziemcom ochrony na terytorium Rzeczypospolitej Polskiej, t.j. Dz.U. 2018, poz. 51, ze zm. Ustawa wykonuje prawo unijne, ale także konwencję NZ dotyczącą statusu uchodźców.

${ }_{23}$ Zob. http://www.ohchr.org/EN/Issues/Pages/Nationality.aspx. 
nej na terytorium państwa, jeśli w przeciwnym przypadku osoba taka stałaby się bezpaństwowcem ${ }^{24}$. Nadanie takie powinno nastąpić z mocy prawa w chwili narodzin bądź na wniosek przez osobę zainteresowaną lub w jej imieniu. Odrzucenie takiego wniosku dopuszczalne jest tylko wyjątkowo, gdy uchybi się wymogom, jakie państwo nadające może sformułować zgodnie z konwencją (ust. 1). W uproszczeniu państwo może wymagać spełnienia jednego lub więcej spośród następujących wymogów: 1) wniosek powinien być złożony przez zainteresowanego między 18. a 21. rokiem życia; 2) osoba zainteresowana mieszka w państwie, gdzie składa wniosek, bezpośrednio przed złożeniem wniosku, przez okres wskazany w prawie krajowym, nie dłuższy niż 5 lat; 3) nie jest osobą podejrzaną lub skazaną za przestępstwo przeciwko bezpieczeństwu narodowemu ani skazana na karę pozbawienia wolności za przestępstwo o wymiarze co najmniej 5 lat; 4) zawsze była bezpaństwowcem (ust. 2). Ponadto dziecko, które urodziło się w związku małżeńskim, w którym matka ma obywatelstwo danego państwa, uzyskuje to obywatelstwo przez urodzenie, gdyby miało zostać bezpaństwowcem (ust. 3). Państwo zobowiązuje się też w ust. 4 do nadania obywatelstwa, jeżeli zainteresowany przekroczył wiek na złożenie wniosku albo nie spełnił wymogu domicylu, o którym mowa w ust. 2, a zarazem nie może uzyskać obywatelstwa państwa-strony, przy czym w chwili jego urodzenia jedno z rodziców miało obywatelstwo państwa, gdzie składany jest wniosek (jeżeli ich obywatelstwo było różne, decyduje się według prawa tego państwa, którego obywatelstwo powinno być nadane). Państwo może jednak wymagać spełnienia jednego lub więcej spośród następujących wymogów: 1) wniosek złożony jest przez osobę spełniającą kryterium wieku ustalone zgodnie z prawem krajowym, wynoszącym co najmniej 23 lata; 2) wnioskodawca mieszkał na terytorium państwa, gdzie składa wniosek, bezpośrednio przed złożeniem wniosku, przez określony czas, nie dłuższy niż 3 lata; 3) osoba zawsze była bezpaństwowcem (ust. 5).

Konwencja przewiduje również obowiązek nadania obywatelstwa państwa osobie urodzonej na jego terytorium, która stałaby się bezpaństwowcem w przypadku, gdy jedno z rodziców miało obywatelstwo tego państwa w chwili urodzenia (jeżeli ich obywatelstwo było różne, decyduje się według prawa tego państwa, którego obywatelstwo powinno być nadane). Nadanie takie powinno nastąpić $\mathrm{z}$ mocy prawa w chwili narodzin bądź na wniosek przez osobę zainteresowaną lub jej imieniu. Odrzucenie takiego wniosku dopuszczalne jest tylko wyjątkowo, gdy uchybi się wymogom, jakie państwo nadające może sformułować zgodnie z konwencją (ust. 1). W uproszczeniu państwo może wymagać spełnienia jednego lub więcej spośród następujących wymogów: 1) wniosek złożony jest przez osobę spełniającą kryterium wieku ustalone zgodnie z prawem krajowym, wynoszącym co najmniej 23 lata; 2) osoba zainteresowana mieszka w państwie, gdzie składa

24 Zgodnie $\mathrm{z}$ art. 3 przyjęto fikcję prawną, że poród na statku lub w samolocie oznacza poród na terytorium państwa, którego banderę statek lub samolot podnosi. 
wniosek, bezpośrednio przed złożeniem wniosku, przez okres wskazany w prawie krajowym, nie dłuższy niż 3 lata; 3) nie jest osobą skazaną za przestępstwo przeciwko bezpieczeństwu narodowemu; 4) zawsze była bezpaństwowcem (ust. 2).

Konwencja przyjmuje domniemanie wzruszalne, zgodnie z którym uznaje się, że rodzice podrzutka znalezionego na terytorium danego państwa posiadali jego obywatelstwo (art. 3).

\section{- Standard prawa polskiego}

Z przytoczonym standardem konwencyjnym korespondują niektóre przepisy ustawy o obywatelstwie polskim ${ }^{25}$, która określa zasady nabycia i utraty obywatelstwa polskiego oraz jego przywracania i potwierdzania, a także uznania za obywatela polskiego. Ustawa zna zarówno przypadek nabycia obywatelstwa z mocy prawa, jak i przez nadanie (art. 4 pkt 1 i 2). Nabycie z mocy prawa regulują art. 14 i n. ustawy. Zgodnie z art. 14 ustawy: [m]ałoletni nabywa obywatelstwo polskie przez urodzenie, w przypadku gdy: 1) co najmniej jedno z rodziców jest obywatelem polskim; 2) urodził się na terytorium Rzeczypospolitej Polskiej, a jego rodzice sa nieznani, nie posiadaja żadnego obywatelstwa lub ich obywatelstwo jest nieokreślone.

$\mathrm{W}$ obu przypadkach chroni się przed bezpaństwowością. Ponadto art. 15 ustawy stanowi, że: [m]ałoletni nabywa obywatelstwo polskie, gdy został znaleziony na terytorium Rzeczypospolitej Polskiej, a jego rodzice sa nieznani.

Pewne znaczenie dla uniknięcia bezpaństwowości dzieci ma również art. 7 ustawy. Zapewnia on, że nadanie obywatelstwa polskiego lub uznanie za obywatela polskiego rodziców dziecka obejmuje także małoletniego znajdującego się pod ich władzą rodzicielską. Jeśli dotyczy to tylko jednego z rodziców, to obejmuje to małoletniego, jeśli drugiemu z nich nie przysługuje władza rodzicielska i drugie z rodziców złożyło oświadczenie o wyrażeniu zgody na nabycie obywatelstwa przez małoletniego.

Konwencja z $1961 \mathrm{r}$. wymaga również umożliwienia nabycia obywatelstwa w określonych warunkach później niż w chwili narodzin. Przy tym w pewnym zakresie (art. 1 ust. 2 i 5, art. 4 ust. 2) daje państwu prawo sformułowania kryteriów, od których spełnienia zależy nadanie obywatelstwa na wniosek.

Z wymogami konwencyjnymi korespondują przepisy ustawy o obywatelstwie polskim dotyczące nadawania obywatelstwa polskiego (art. 18 i n.) oraz uznania za obywatela polskiego (art. 30 i n.). Przepisy te nie stanowią w żadnym razie odwzorowania postanowień konwencyjnych.

Ustawa o obywatelstwie polskim pozwala na nadawanie obywatelstwa na wniosek (art. 19). Z przepisów ustawy wynika zarazem pośrednio, że samodzielnie wniosek taki może złożyć wyłącznie osoba dorosła. Natomiast, zgodnie z art. 8, gdy wniosek dotyczy małoletniego, który ukończył 16. rok życia, konieczne jest dołączenie do wniosku oświadczenia o wyrażeniu zgody przez małoletniego.

25 Ustawa z 2 kwietnia 2009 r. o obywatelstwie polskim, t.j. Dz.U. 2017, poz. 1462, ze zm. 
Ustawa o obywatelstwie polskim nie wprowadza jednak obowiązku nadania obywatelstwa. Prezydent RP może je nadać albo odmówić nadania (art. 18, art. 25). Tymczasem konwencja z 1961 r. domaga się nadania obywatelstwa bezpaństwowcowi na wniosek, a jedynie pozwala państwu wprowadzić kryteria nadania.

Ustawa o obywatelstwie polskim zna także instytucję uznania za obywatela polskiego, którą można łączyć z konwencyjnym nadaniem obywatelstwa. Dotyczy ona siedmiu kategorii cudzoziemców wymienionych w art. 30 ust. 1 ustawy. Tutaj również formułowane są kryteria uznania w odniesieniu do poszczególnych kategorii osób. Uznanie również następuje na wniosek (art. 32). Zgodnie $\mathrm{z}$ art. 30 ust. 1 pkt 2 ustawy za obywatela polskiego uznaje się m.in.: cudzoziemca przebywajacego nieprzerwanie na terytorium Rzeczypospolitej Polskiej co najmniej od 2 lat na podstawie zezwolenia na pobyt stały, zezwolenia na pobyt rezydenta długoterminowego Unii Europejskiej lub prawa stałego pobytu, który: a) pozostaje co najmniej od 3 lat $w$ związku małżeńskim zawartym z obywatelem polskim lub b) nie posiada żadnego obywatelstwa.

Wymóg dwuletniego pobytu jest zgodny z konwencją (art. 1 ust. 2 lit. b; aczkolwiek konwencja w ramach jednego wymogu mówi o pobycie nieprzerwanym co najwyżej 5-letnim lub w sumie o 10 latach pobytu). Ustawa o obywatelstwie polskim wymaga jednak dodatkowo urzędowo potwierdzonej znajomości języka polskiego (ust. 2 art. 30; nie dotyczy on jedynie małoletniego cudzoziemca), co nie jest przewidziane konwencją z 1961 r. Ponadto odmawia się uznania cudzoziemca za obywatela polskiego (art. 31 pkt 2 ustawy) m.in. w przypadku, gdy: nabycie przez niego obywatelstwa polskiego stanowi zagrożenie dla obronności lub bezpieczeństwa państwa albo ochrony bezpieczeństwa i porządku publicznego.

Konwencja z 1961 r. dopuszcza posługiwanie się kryterium podejrzenia lub skazania (na karę pozbawienia wolności na okres co najmniej 5 lat) za przestępstwa przeciwko bezpieczeństwu narodowemu (art. 1 ust. 2 lit. c; art. 4 ust. 2 lit. c).

Ustawa nie zapewnia też wykonania art. 1 ust. 4 konwencji z 1961 r. (bezpaństwowiec niezdolny do uzyskania obywatelstwa strony konwencji, niespełniający wymagań wiekowych lub domicylu) czy art. 4 (nadanie obywatelstwa osobie, której rodzice lub rodzic w momencie narodzin byli obywatelami polskimi, a która urodziła się poza Polską).

\section{- Utrata obywatelstwa wskutek zmiany stanu cywilnego}

- Standard konwencyjny

Zagadnieniu bezpaństwowości w razie utraty obywatelstwa poświęcono w konwencji z 1961 r. art. 5 i 6. Pierwszy z nich dotyczy utraty obywatelstwa wskutek zmiany statusu cywilnego osoby. Jeżeli prawo krajowe przewiduje taką sytuację, to utrata może nastąpić wyłącznie wówczas, gdy osoba taka uzyska lub ma obywatelstwo innego państwa. Gdy utrata dotyczy nieślubnego dziecka, powinno ono mieć możliwość odzyskania obywatelstwa na wniosek i z poszanowaniem 
wymogów, które nie będą bardziej rygorystyczne niż te z art. 1 ust. 2 konwencji (art. 5). Artykuł 6 konwencji odnosi się do pochodnej utraty obywatelstwa, tj. przypadku, gdy utrata obywatelstwa przez małżonka lub dzieci wynika $\mathrm{z}$ utraty obywatelstwa zainteresowanej osoby. $\mathrm{W}$ takim wypadku prawo krajowe także powinno uzależniać utratę od posiadania lub nabycia innego obywatelstwa.

\section{- Standard prawa polskiego}

Ustawa o obywatelstwie polskim przewiduje, że:

- w odniesieniu do zawarcia związku małżeńskiego przez obywatela polskiego z cudzoziemcem nie powoduje ono zmian w obywatelstwie małżonków (art. 5), a zatem ani mąż, ani żona nie traçą ewentualnie posiadanego obywatelstwa polskiego; ustawa nie zawiera analogicznego rozwiązania $\mathrm{w}$ razie rozwodu lub unieważnienia małżeństwa,

- zmiany w ustaleniu osoby albo obywatelstwa jednego lub obojga rodziców podlegają uwzględnieniu przy określeniu obywatelstwa małoletniego, jeżeli nastąpiły przed upływem roku od dnia urodzenia się małoletniego (art. 6 ust. 1); ustawa nie wskazuje, co dzieje się, gdy z ustalenia obywatelstwa rodziców wynika, że nie mają żadnego obywatelstwa,

- w odniesieniu do sądowego ustalenia osoby ojca (zaprzeczenie ojcostwa, unieważnienie uznania) - uwzględnia się je przy określeniu obywatelstwa małoletniego, chyba że małoletni osiągnął już pełnoletność lub za jego zgodą, jeżeli ukończył 16 lat (art. 6 ust. 2); ustawa nie wskazuje, co dzieje się, gdy ze zmian dotyczących ojca wynika, że dziecko staje się bezpaństwowcem,

- małoletni cudzoziemiec, przysposobiony przez osobę lub osoby posiadające obywatelstwo polskie, nabywa obywatelstwo polskie, jeżeli przysposobienie pełne nastąpiło przed ukończeniem przez niego 16 lat; w tym wypadku przyjmuje się, że małoletni cudzoziemiec nabył obywatelstwo polskie z dniem urodzenia (art. 16).

Z przepisów ustawy wynika, że nie zapewniają one utrzymania obywatelstwa polskiego $\mathrm{w}$ sytuacji, gdy zmiany związane z małżeństwem prowadziłyby do bezpaństwowości.

- Zrzeczenie się obywatelstwa, ubieganie się o obce obywatelstwo, utrata obywatelstwa na skutek wyjazdu, zamieszkiwania zagranicą, braku zameldowania i innych zdarzeń podobnych

- Standard konwencyjny

Artykuł 7 konwencji z 1961 r. dotyczy zrzeczenia się obywatelstwa. Jeśli zatem prawo krajowe dopuszcza zrzeczenie, to takie zrzeczenie nie powinno powodować bezpaństwowości. Jednak postanowienia tego nie stosuje się, gdyby naruszało ono art. 13 i 14 Powszechnej deklaracji praw człowieka. Podobnie - ubieganie 
się o obce obywatelstwo nie może prowadzić do bezpaństwowości. Osoba taka powinna zatem uzyskać takie obywatelstwo lub otrzymać decyzję, że zostanie mu ono nadane (art. 7 ust. 1 i 2 konwencji).

Zainteresowany nie powinien też tracić obywatelstwa, stając się bezpaństwowcem, na skutek wyjazdu, zamieszkiwania zagranicą (chyba że chodzi o obywatela z naturalizacji, który mieszka zagranicą co najmniej 7 kolejnych lat i nie składa oświadczenia o zamiarze zachowania obywatelstwa), braku zarejestrowania i innych zdarzeń podobnych. Ponadto w przypadku osób urodzonych zagranicą można uzależnić zachowanie obywatelstwa od zamieszkania w czasie osiągnięcia dojrzałości w tym państwie lub zarejestrowania. Niezależnie od tego osoba nie może utracić obywatelstwa, stając się bezpaństwowcem, $\mathrm{z}$ innych niezakazanych wyraźnie w konwencji powodów (ust. 3-5).

- Standard prawa polskiego

Ustawa o obywatelstwie reguluje problematykę zrzeczenia się obywatelstwa $\mathrm{w}$ art. 46 i n. Zrzeczenie się jest zatem dopuszczalne tylko za zgodą Prezydenta RP (art. 46 i 47). Ustawa nie zawiera gwarancji, że takie zrzeczenie nie doprowadzi do bezpaństwowości.

Ustawa nie przewiduje innych przypadków utraty obywatelstwa, poza zrzeczeniem się (zob. też art. 34 ust. 2 Konstytucji).

\section{- Pozbawienie obywatelstwa}

\section{- Standard konwencyjny}

Państwo-strona konwencji z 1961 r. nie może pozbawić obywatelstwa, jeśli jego skutkiem będzie bezpaństwowość (art. 8 ust. 1). Konwencja przewiduje w tym artykule, że pozbawienie obywatelstwa może nastąpić tylko na określonych warunkach (art. 7 ust. 4 i 5, uzyskanie obywatelstwa nastąpiło na skutek świadomego wprowadzenia w błąd lub oszustwa). Ponadto państwo może zachować prawo pozbawienia obywatelstwa przez złożenie deklaracji zgodnie z ust. 3 art. 8, tj. w razie naruszenia obowiązku lojalności lub złożenia przysięgi lub oświadczenia o wierności wobec innego państwa. Pozbawienie obywatelstwa $\mathrm{w}$ innych przypadkach powinno być niedozwolone, a samo powinno zachowywać standardy określenia pozbawienia obywatelstwa w ustawie, a także prawa do obrony. Ponadto, zgodnie z art. 9 konwencji, nie można pozbawiać osoby lub grupy osób obywatelstwa z powodów rasowych, etnicznych, religijnych lub politycznych.

- Standard prawa polskiego

Prawo polskie nie przewiduje pozbawienia obywatelstwa polskiego (art. 34 ust. 2 Konstytucji). Akty tego rodzaju stanowiłyby naruszenie Konstytucji i ustaw. Oznacza to, że prawo polskie jest zgodne z wymogami konwencyjnymi. 


\section{- Cesja terytorialna}

- Standard konwencyjny

Konwencja z 1961 r. przewiduje również zobowiązanie włączenia do zawieranych przez siebie (także z państwem niebędącym stroną) traktatów cesji terytorialnej klauzuli pozwalającej zachować osobom dotkniętym transferem obywatelstwo. Jeśli taka klauzula nie zostanie włączona, należy nadać osobom zainteresowanym obywatelstwo, jeśli miałyby stać się bezpaństwowcami (art. 10 konwencji).

- Standard prawa polskiego

Prawo polskie nie odnosi się do kwestii bezpaństwowości w przypadku cesji terytorialnej. Materia ta podlega ewentualnej regulacji umownej. Oznacza to, że w zakresie, w jakim konwencja wymaga zapewnienia, że nie dojdzie do bezpaństwowości w razie braku odpowiedniej klauzuli w umowie cesji terytorialnej, ustawodawstwo polskie nie spełnia standardu konwencyjnego.

\section{Standardy ochronne określające status prawny bezpaństwowca}

\section{- Zasady ogólne}

- Standard konwencyjny

Konwencja z 1954 r. wymienia najpierw kilka zasad ogólnych o zróżnicowanym charakterze. Formułuje ogólne zobowiązanie dla każdego bezpaństwowca przede wszystkim do przestrzegania prawa i porządku publicznego państwa przyjmującego (art. 1). Ponadto ustanawia ogólne standardy traktowania bezpaństwowców: 1) zakaz dyskryminacji z uwagi na rasę, religię, państwo pochodzenia; 2) standard traktowania narodowego co do wolności praktyk religijnych i edukacji religijnej dzieci (art. 3 i 4). Konwencja wyznacza minimalny standard traktowania bezpaństwowców, tj. tak jak cudzoziemców, chyba że konwencja zawiera rozwiązania bardziej korzystne. Poza tym zawiera regulację dotyczącą zwolnienia spod reguły traktowania na zasadzie wzajemności (art. 7). Ustanawia możliwości poszerzania ochrony, także uwzględniania ochrony pozakonwencyjnej (art. 7 ust. 3 i 4, art. 5). Do bezpaństwowców nie stosuje się środków wyjątkowych tylko dlatego, że byli uprzednio obywatelami obcego państwa, wobec którego podejmuje się takie środki (art. 8). Zarazem dopuszcza się stosowanie środków tymczasowych w razie wojny lub innych poważnych i wyjątkowych okoliczności, koniecznych ze względu na bezpieczeństwo wewnętrzne (art. 9) ${ }^{26}$.

26 Pomijam postanowienia art. 10 (kontynuacja zamieszkiwania w razie przesiedleńców z II wojny światowej) i art. 11 (marynarzy bezpaństwowców - obowiązek ułatwień w uzyskaniu obywatelstwa). 
Konwencja z 1954 r. posługuje się w szczegółowych rozwiązaniach dotyczących położenia bezpaństwowców dwoma standardami: standardem traktowania narodowego $(\mathrm{KN})$ oraz standardem najwyższego uprzywilejowania (KNU). Pierwszy z nich nakazuje traktowanie tak jak własnych obywateli, drugi - jak cudzoziemców w takich samych okolicznościach (wyjaśnia też rozumienie tego ostatniego określenia w art. 6; chodzi o wymogi domicylu - długości i warunków pobytu lub zamieszkania).

W tym kontekście należy pamiętać, że w przypadku Polski jako państwa członkowskiego Unii Europejskiej, dla standardu traktowania narodowego punktem odniesienia jest nie tylko traktowanie obywateli polskich, lecz również, co do zasady, obywateli państw członkowskich UE (ich traktowanie nie oznacza traktowania cudzoziemców w rozumieniu konwencji z 1954 r.). Standard najwyższego uprzywilejowania oznacza zatem porównanie z obywatelami państw trzecich (spoza Unii Europejskiej).

- Standard prawa polskiego

W odniesieniu do zakazu dyskryminacji bezpaństwowców (art. 3 konwencji z 1954 r.) Konstytucja zakazuje dyskryminacji w szerszym zakresie, nie różnicując uprawnionych i nie ograniczając kryteriów niedozwolonej dyskryminacji (art. 32 Konstytucji). Co do gwarancji wolności religijnej w zakresie ustalonym konwencją (art. 4), w art. 53 Konstytucji zawarta jest odpowiednia reguła gwarancyjna, nieróżnicująca osób w zakresie statusu obywatelskiego. Co więcej, ustawa o gwarancjach wolności sumienia i wyznania ${ }^{27}$ wyraźnie przewiduje w art. 7, że cudzoziemcom, a także bezpaństwowcom przebywającym na terytorium RP zapewnia się korzystanie z wolności sumienia i wyznania na równi z obywatelami polskimi (standard traktowania narodowego), co wypełnia wymogi konwencyjne.

Konwencja z 1954 r. traktuje bezpaństwowców tak jak cudzoziemców, chyba że zawiera rozwiązania bardziej korzystne. Także polska ustawa o cudzoziemcach obejmuje zakresem swojej regulacji bezpaństwowców.

Prawo polskie nie przewiduje też szczególnego (niekorzystnego) traktowania bezpaństwowców w razie stanu wojennego (art. 18 i n. ustawy o stanie wojennym oraz o kompetencjach Naczelnego Dowódcy Sił Zbrojnych i zasadach jego podległości konstytucyjnym organom Rzeczypospolitej Polskiej ${ }^{28}$, wyjątki dotyczą swobody wjazdu i pobytu oraz mienia - art. 7 ust. 2, art. 28 ust. 1 pkt 3) czy stanu wyjątkowego (art. 21 ustawy o stanie wyjątkowym ${ }^{29}$ ). W tym względzie

27 Ustawa z 17 maja 1989 r. o gwarancjach wolności sumienia i wyznania, t.j. Dz.U. 2017, poz. 1153.

28 Ustawa z 29 sierpnia 2002 r. o stanie wojennym oraz o kompetencjach Naczelnego Dowódcy Sił Zbrojnych i zasadach jego podległości konstytucyjnym organom Rzeczypospolitej Polskiej, t.j. Dz.U. 2017, poz. 1932.

29 Ustawa z 21 czerwca 2002 r. o stanie wyjątkowym, t.j. Dz.U. 2017, poz. 1928. 
jednak pełna ocena zgodności z konwencją (art. 8 i 9) byłaby możliwa dopiero przy uwzględnieniu praktyki stosowania przepisów ustawowych.

\section{- Status prawny}

- Standard konwencyjny

Zasadą ogólną jest, że status osobowy bezpaństwowca jest regulowany prawem państwa przyjmującego, a prawa nabyte $\mathrm{z}$ nim związane, zwłaszcza wynikające $\mathrm{z}$ małżeństwa, muszą być szanowane przez państwo przyjmujące, zgodnie $\mathrm{z}$ art. 12 konwencji z $1954 \mathrm{r}$. Ponadto konwencja przewiduje: 1) w stosunku do mienia nieruchomego i ruchomego - KNU; 2) własności intelektualnej i przemysłowej - KN; 3) prawa zrzeszania się $\mathrm{w}$ organizacje inne niż polityczne, nienastawione na zysk oraz w związki zawodowe - KNU; 4) prawa do sądu - KN (art. 13-16 konwencji).

\section{- Standard prawa polskiego}

W odniesieniu do statusu osobowego bezpaństwowców stosuje się niewątpliwie prawo polskie. Dotyczy to np. ustawy - Prawo o aktach stanu cywilnego ${ }^{30}$ (jako do cudzoziemców). Także Kodeks cywilny ${ }^{31} \mathrm{w}$ zakresie prawa osobowego, rzeczowego i spadkowego stosuje się do bezpaństwowców (jako do osób fizycznych). W przypadku nabywania nieruchomości przez bezpaństwowców stosuje się wszakże ustawę o nabywaniu nieruchomości przez cudzoziemców ${ }^{32}$. Ustawa ta dotyczy cudzoziemców, ale należy ją odnosić także do bezpaństwowców (art. 1 ust. 2 pkt 1). Wprawdzie wprowadza ona ograniczenia, ale nie różnicuje statusu bezpaństwowca i cudzoziemca, co spełnia standard konwencyjny.

Jeśli chodzi o prawo własności intelektualnej i przemysłowej, to zastosowanie znajduje najpierw ustawa o prawie autorskim i prawach pokrewnych (bezpaństwowiec będący podmiotem prawa autorskiego w rozumieniu art. $8 \mathrm{in}$. ${ }^{33}$. Ponadto znaczenie ma ustawa - Prawo własności przemysłowej ${ }^{34}$. W tym wypadku ustawa wyróżnia kategorię osób zagranicznych, do której należą m.in. osoby niemające obywatelstwa polskiego (art. 3 ust. 1 pkt 2). Jeśli nie ma odpowiednich umów międzynarodowych, to mogą one korzystać z praw i ochrony wynikających $\mathrm{z}$ ustawy na zasadzie wzajemności. Konwencja jednak wymaga, aby wobec

30 Ustawa z 28 listopada 2014 r. - Prawo o aktach stanu cywilnego, t.j. Dz.U. 2016, poz. 2064, ze zm.

31 Ustawa z 23 kwietnia 1964 r. - Kodeks cywilny, t.j. Dz.U. 2018, poz. 1025.

32 Ustawa z 24 marca 1920 r. o nabywaniu nieruchomości przez cudzoziemców, t.j. Dz.U. 2017, poz. 2278.

33 Ustawa z 4 lutego 1994 r. o prawie autorskim i prawach pokrewnych, t.j. Dz.U. 2017, poz. 880 , ze zm.

34 Ustawa z 20 lipca 2000 r. - Prawo własności przemysłowej, t.j. Dz.U. 2017, poz. 776. 
bezpaństwowców nie stosować przynajmniej po upływie 3 lat wymogu wzajemności (art. 7 ust. 2).

W odniesieniu do zrzeszania się ustawa - Prawo o stowarzyszeniach ${ }^{35}$ stano- $^{-}$ wi w art. 4, że: 1. Cudzoziemcy mający miejsce zamieszkania na terytorium Rzeczypospolitej Polskiej moga zrzeszać się $w$ stowarzyszeniach, zgodnie z przepisami obowiązujacymi obywateli polskich. 2. Cudzoziemcy niemajacy miejsca zamieszkania na terytorium Rzeczypospolitej Polskiej moga wstępować do stowarzyszeń, które przewiduja taka możliwość.

Konwencja z 1954 r. wymaga traktowania bezpaństwowców jak cudzoziemców (art. 15). W rezultacie polska regulacja nie narusza standardu konwencyjnego.

\section{- Zatrudnienie i wynagrodzenie}

- Standard konwencyjny

Gdy chodzi o sferę stosunków pracy, to konwencja z 1954 r. ustanawia następujące standardy traktowania bezpaństwowców: 1) prawo do zatrudnienia za wynagrodzeniem - KNU (z obowiązkiem rozpatrzenia zbliżenia do KN); 2) prawo do samozatrudnienia - KNU; 3) prawo do wykonywania wolnych zawodów - KNU (art. 17-19).

- Standard prawa polskiego

W kwestii zatrudniania i wynagradzania do bezpaństwowców stosuje się przepisy dotyczące zatrudniania cudzoziemców w Polsce z ustawy o promocji zatrudnienia i instytucjach rynku pracy (art. 1 ust. 3) ${ }^{36}$. Ustawa nie wspomina wprost o bezpaństwowcach, ale można ich lokować w różnych kategoriach ustawowych cudzoziemców (art. 2 ust. 1 pkt 7). Konwencja z 1954 r. wymaga traktowania takiego jak cudzoziemców, co ustawa gwarantuje.

$\mathrm{W}$ odniesieniu do samozatrudnienia oraz w zakresie wykonywania wolnych zawodów przez bezpaństwowców znaczenie mają ustawa - Prawo przedsiębiorców $^{37}$ oraz ustawa o zasadach uczestnictwa przedsiębiorców zagranicznych i innych osób zagranicznych w obrocie gospodarczym na terytorium Rzeczypospolitej Polskiej ${ }^{38}$. Pierwsza z nich, niezrelatywizowana wyraźnie do cudzoziemców (i bezpaństwowców), nie wprowadza rozróżnienia między obywatelami a cudzoziemcami, kierując się kryterium przedsiębiorcy działającego na terytorium RP i nakazując równe traktowanie wszystkich przedsiębiorców (jest nim także oso-

35 Ustawa z 7 kwietnia 1989 r. - Prawo o stowarzyszeniach, t.j. Dz.U. 2017, poz. 210, ze zm.

36 Ustawa z 20 kwietnia 2004 r. o promocji zatrudnienia i instytucjach rynku pracy, t.j. Dz.U. 2017, poz. 1065, ze zm.

37 Ustawa z 6 marca 2018 r. - Prawo przedsiębiorców, Dz.U. poz. 646.

38 Ustawa z 6 marca 2018 r. o zasadach uczestnictwa przedsiębiorców zagranicznych i innych osób zagranicznych w obrocie gospodarczym na terytorium Rzeczypospolitej Polskiej, Dz.U. poz. 649. 
ba fizyczna) w zakresie podejmowania, wykonywania i zakończenia działalności (art. 1, 3 i 4 ustawy).

Druga z ustaw, dotycząca tak działalności gospodarczej, jak i świadczenia usług, tworzy jednak rozwiązania szczególne dotyczące zwłaszcza cudzoziemców rozumianych w niej jako osoby zagraniczne działające na terytorium RP (art. 1 i 2). Przy tym w odniesieniu do działalności gospodarczej ustawa wprowadza $\mathrm{w}$ art. 4 rozróżnienie $\mathrm{w}$ standardzie traktowania na osoby zagraniczne z państw członkowskich Unii Europejskiej lub Europejskiego Obszaru Gospodarczego oraz inne osoby zagraniczne, aczkolwiek wszystkim zapewnia traktowanie narodowe. Trzeba zauważyć, że w ustawie istnieje wada legislacyjna (niespójność), gdyż art. 3 pkt 5 lit. a wskazuje, że osobą zagraniczną jest m.in. osoba fizyczna nieposiadająca obywatelstwa polskiego, a zatem teoretycznie także bezpaństwowiec. Tymczasem art. 4, który wyznacza standard traktowania, ogranicza standard traktowania do obywateli innych państw, a nie osób zagranicznych z innych państw niż państwa członkowskie UE/EOG. Oznacza to, że ustawa nie spełnia wymagań konwencji z 1954 r. W stosunku do świadczenia usług ustawa stanowi, że osoby zagraniczne inne niż z państw członkowskich UE/EOG mogą czasowo świadczyć usługi na zasadach określonych w wiążących RP umowach międzynarodowych, a w ich braku na zasadzie wzajemności (art. 5). I w tym przypadku powstaje sprzeczność z konwencją z 1954 r., ponieważ nie uzależnia ona świadczenia usług od istnienia umów międzynarodowych, a ponadto domaga się zwolnienia z wymogu wzajemności, przynajmniej po upływie 3 lat od uzyskania legalnego zamieszkania na terytorium państwa-strony (art. 7).

Ustawa o cudzoziemcach wskazuje też na wymogi wstępne dotyczące zatrudnienia lub wykonywania działalności gospodarczej, w tym wolnych zawodów (np. art. 142 i n.), które stosuje się jednakowo do cudzoziemców i bezpaństwowców. Odpowiada to wymogom konwencyjnym.

\section{- Opieka społeczna}

- Standard konwencyjny

W dziedzinie opieki socjalnej konwencja wymaga: 1) w razie sytuacji niedostatku produktów - KN; 2) zakwaterowania - KNU; 3) edukacji publicznej podstawowej - KN, ponadpodstawowej (dostęp do nauki, ale też uznawanie dyplomów i stopni, stypendiów, kosztów i opłat) - KNU; 4) pomocy ze środków publicznych $\mathrm{KN}$; 5) standardy prawa pracy i zabezpieczenia społecznego - KN (art. 17-24).

- Standard prawa polskiego

W odniesieniu do korzystania przez bezpaństwowców z pomocy państwa znaczenie ma ustawa o pomocy społecznej ${ }^{39}$. Ustawa obejmuje nią niektóre, wąskie

39 Ustawa z 12 marca 2004 r. o pomocy społecznej, t.j. Dz.U. 2017, poz. 1769, ze zm. 
kategorie cudzoziemców (art. 5 pkt 2, art. 5a), nie wskazując jednak wyraźnie, że chodzi tutaj także o bezpaństwowców. Regulacja ta pozostaje niejasna co do jej zastosowania wobec bezpaństwowców (wyraźnie większy nacisk kładzie się na uchodźców lub osoby znajdujące się w sytuacji szczególnej, czasowej). Tymczasem konwencja wymaga zapewnienia traktowania narodowego.

W zakresie prawa pracy i zabezpieczenia społecznego stosuje się ustawy Kodeks pracy ${ }^{40}$ oraz ustawę o systemie ubezpieczeń społecznych ${ }^{41}$. Ustawy te stosują kryterium podmiotowe niezwiązane z obywatelstwem. Nie wydaje się zatem, aby standard traktowania bezpaństwowców odbiegał od traktowania obywateli, czego wymaga konwencja.

Jeśli chodzi o szkolnictwo, Konstytucja gwarantuje prawo do nauki, lecz stwierdza, że władze publiczne zapewniają obywatelom powszechny i równy dostęp do wykształcenia (art. 70 ust. 4). Z kolei ustawa - Prawo oświatowe ${ }^{42}$ nie różnicuje w statusie obywateli i cudzoziemców (bezpaństwowców), obejmując obowiązkiem szkolnym dzieci w wieku 7 lat do 18. roku życia albo ukończenia szkoły ponadpodstawowej i nakazując traktowanie osób niebędących obywatelami polskimi tak jak obywateli polskich (art. 35 ust. 2, art. 165 ust. 1 i 2), co wykracza poza wymogi konwencyjne. W przypadku szkolnictwa wyższego ustawa Prawo o szkolnictwie wyższym ${ }^{43}$ przewiduje odmienne od obywateli traktowanie cudzoziemców (w tym bezpaństwowców, art. 43), różnicując jednak traktowanie w obrębie cudzoziemców (ust. 2). Nie koresponduje to z konwencją z 1954 r.

\section{- Środki administracyjne}

- Standard konwencyjny

W sferze stosowania środków administracyjnych konwencja z 1954 r. wymaga, aby państwa-strony zapewniły pomoc administracyjną, jeśli korzystanie z praw przez bezpaństwowca wymaga pomocy. Chodzi tutaj w szczególności o dostarczanie niezbędnych dokumentów lub świadectw. Wszelkie opłaty z tytułu czynności administracyjnych muszą być umiarkowane, porównywalne do pobieranych za podobne usługi od obywateli (art. 25). Ponadto konwencja domaga się KNU w odniesieniu do swobody przemieszczania się (istnieje obowiązek wydania koniecznych dokumentów tożsamości osobom nieposiadającym ważnego dokumentu, a także co do zasady dokumentów podróży, art. 26-28). W kwestii opodatkowania i ceł konwencja wprowadza standard traktowania na-

40 Ustawa z 26 czerwca 1974 r. - Kodeks pracy, t.j. Dz.U. 2018, poz. 917, ze zm.

41 Ustawa z 13 października 1998 r. o systemie ubezpieczeń społecznych, t.j. Dz.U. 2017, poz. 1778 , ze zm.

42 Ustawa z 14 grudnia 2016 r. - Prawo oświatowe, t.j. Dz.U. 2018, poz. 996, ze zm.

43 Ustawa z 27 lipca 2005 r. - Prawo o szkolnictwie wyższym, t.j. Dz.U. 2017, poz. 2183, ze zm. 
rodowego (art. 29). Co do transferu aktywów nabytych w państwie, w którym bezpaństwowcy otrzymali zezwolenie na przesiedlenie, konwencja wymaga jego umożliwienia (art. 30). Wreszcie, co do wydalenia, konwencja ustanawia zasadę, że może ono nastąpić jedynie w przypadkach uzasadnionych względami bezpieczeństwa narodowego lub publicznego. Wydalenie może mieć miejsce tylko na podstawie decyzji wydanej zgodnie z odpowiednią procedurą prawną. Co do zasady bezpaństwowiec ma też mieć prawo do obrony i reprezentacji. W razie wydalenia może być wprowadzany okres karencji (art. 31).

\section{- Standard prawa polskiego}

Konwencja z 1954 r. wymaga udzielenia pomocy bezpaństwowcom w sprawach administracyjnych. W Polsce może być ona świadczona na zasadach ogólnie mających zastosowanie do cudzoziemców. Prawo polskie nie przewiduje szczególnych rozwiązań dla bezpaństwowców.

W odniesieniu do swobody przemieszczania się bezpaństwowców, łącznie z obowiązkiem wydawania dokumentów tożsamości czy dokumentów podróży, znaczenie ma ustawa o cudzoziemcach. Tak jak w wielu innych przypadkach ustawa nie rozróżnia cudzoziemca i bezpaństwowca (art. 226 i n.). Ustawa przewiduje możliwość wydania na wniosek cudzoziemca polskich dokumentów tożsamości i dokumentów podróży cudzoziemcowi (art. 226 i 229). Oznacza to, że ustawa nie gwarantuje niezbędnej ochrony bezpaństwowcowi, wobec którego konwencja z 1954 r. wymaga wydania dokumentów tożsamości, jeśli nie ma ważnych dokumentów podróży (art. 27). Konwencja odróżnia też dokumenty tożsamości (co do wydania których jest bardziej rygorystyczna) i dokumenty podróży (co do których dopuszcza odstępstwa z uwagi na ochronę bezpieczeństwa narodowego i porządku publicznego, art. 28).

Jednym z zagadnień uregulowanych konwencją z 1954 r. jest też ochrona bezpaństwowców legalnie przebywających na terytorium państwa-strony przed wydaleniem (art. 31). W tej materii ustawodawstwo polskie, zwłaszcza ustawa o cudzoziemcach, nie przewiduje szczególnego traktowania bezpaństwowców. Stosuje się do nich zasady dotyczące cudzoziemców. Przy tym ustawa wprowadziła w miejsce decyzji o wydaleniu konstrukcję decyzji zobowiązującej cudzoziemca do powrotu (art. 299 i n. $)^{44}$. Przyczyny wydania takiej decyzji określa bardzo rozbudowany art. 302 ustawy. Szerzej widziane są tu przyczyny związane z ochroną interesów narodowych. Ustawa wymienia bowiem: względy obronności lub bezpieczeństwa państwa lub ochrony bezpieczeństwa i porzadku publicznego lub interes Rzeczypospolitej Polskiej (ust. 1 pkt 9). Oznacza to niedostosowanie do konwencji, która aprobuje jedynie względy bezpieczeństwa narodowego lub

${ }^{44}$ Wyjątek odnosi się do ustawy z 14 lipca 2006 r. o wjeździe na terytorium Rzeczypospolitej Polskiej, pobycie oraz wyjeździe z tego terytorium obywateli państw członkowskich Unii Europejskiej i członków ich rodzin, t.j. Dz.U. 2017, poz. 900, ze zm. 
bezpieczeństwa publicznego (art. 31 ust. 1). Natomiast ustawa z pewnością spełnia wymogi proceduralne stawiane w konwencji.

Co do podatków i ceł, Polska ustanawia samodzielnie jedynie podatki (na zasadzie zharmonizowanej). W zakresie ceł stosuje się rozporządzenia Unii Europejskiej. Gdy chodzi o podatki, zwłaszcza podatek dochodowy od osób fizycznych, to ustawę o podatku dochodowym od osób fizycznych ${ }^{45}$ stosuje się tylko do osób fizycznych osiągających na terytorium RP (w rozumieniu art. 5) dochody w rozumieniu art. 3 ustawy. Ustawa ta nie rozróżnia pod tym względem cudzoziemców i bezpaństwowców, stosując do nich formalnie standard traktowania narodowego (pewne znaczenie ma miejsce zamieszkania, ale jest ono istotne tylko o tyle, o ile trzeba ustalić, jaki dochód podlega opodatkowaniu).

\section{Bibliografia}

Nascimbene B., Le droit de la nationalité et le droit des organisations d'intégration régionales. Vers de nouveaux statuts de résidents?, RCADI 2013, vol. 367, https://doi. org/10.1163/ej.9789004267930.253-414.

Stiller M., Statlessness in International Law: A Historic Overview, DAJV Newsletter 2012, No. 3.

UNHCR, Guidelines on Statelessness No. 1: The definition of „Stateless Person” in Article 1(1) of the 1954 Convention relating to the Status of Stateless Persons, HCR/GS/12/01, 20 February 2012, http://www.refworld.org/pdfid/4f4371b82.pdf.

Worster W.T., The Presumption of Customary International Law: A Case Study of Child Stateleness, https://papers.ssrn.com/sol3/papers.cfm?abstract_id=3091912, https:// doi.org/10.2139/ssrn.3091912.

45 Ustawa z 26 lipca 1991 r. o podatku dochodowym od osób fizycznych, t.j. Dz.U. 2018, poz. 200, ze zm. 